Brief Report

\title{
Altered mRNA and Protein Expression of Monocarboxylate Transporter MCT1 in the Cerebral Cortex and Cerebellum of Prion Protein Knockout Mice
}

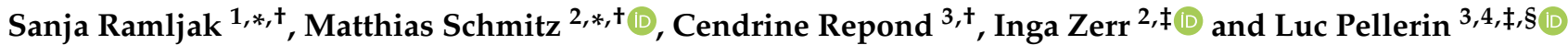 \\ 1 Digital Diagnostics AG, 55129 Mainz, Germany \\ 2 Department of Neurology, University Medicine Goettingen and The German Center for Neurodegenerative \\ Diseases (DZNE), 37075 Goettingen, Germany; ingazerr@med.uni-goettingen.de \\ 3 Département de Physiologie, Université de Lausanne, 1005 Lausanne, Switzerland; \\ Cendrine.Repond@unil.ch (C.R.); luc.pellerin@univ-poitiers.fr (L.P.) \\ 4 Centre de Résonance Magnétique des Systèmes Biologiques, UMR5536 CNRS, LabEx TRAIL-IBIO, \\ Université de Bordeaux, 33760 Bordeaux CEDEX, France \\ * Correspondence: sr@digid.com (S.R.); matthias.schmitz@med.uni-goettingen.de (M.S.); \\ Tel.: +49-5513910454 (M.S.) \\ + These authors contributed equally to this work. \\ $\ddagger \quad$ These authors contributed equally to this work to this study as senior authors. \\ $\S$ Current address: Inserm U1082, Université de Poitiers, 86021 Poitiers CEDEX, France.
}

Citation: Ramljak, S.; Schmitz, M.; Repond, C.; Zerr, I.; Pellerin, L. Altered mRNA and Protein Expression of Monocarboxylate Transporter MCT1 in the Cerebral Cortex and Cerebellum of Prion Protein Knockout Mice. Int. J. Mol. Sci. 2021, 22, 1566. https://doi.org/ $10.3390 /$ ijms 22041566

Academic Editor: Noriyuki Koibuchi Received: 12 January 2021

Accepted: 27 January 2021

Published: 4 February 2021

Publisher's Note: MDPI stays neutral with regard to jurisdictional claims in published maps and institutional affiliations.

Copyright: (c) 2021 by the authors. Licensee MDPI, Basel, Switzerland. This article is an open access article distributed under the terms and conditions of the Creative Commons Attribution (CC BY) license (https:// creativecommons.org/licenses/by/ $4.0 /)$

\begin{abstract}
The effect of a cellular prion protein $\left(\mathrm{PrP}^{\mathrm{c}}\right)$ deficiency on neuroenergetics was primarily analyzed via surveying the expression of genes specifically involved in lactate/pyruvate metabolism, such as monocarboxylate transporters (MCT1, MCT2, MCT4). The aim of the present study was to elucidate a potential involvement of $\mathrm{PrP}^{\mathrm{C}}$ in the regulation of energy metabolism in different brain regions. By using quantitative real-time polymerase chain reaction (qRT-PCR), we observed a marked reduction in MCT1 mRNA expression in the cortex of symptomatic Zürich I Prnp ${ }^{-/-}$ mice, as compared to their wild-type (WT) counterparts. MCT1 downregulation in the cortex was accompanied with significantly decreased expression of the MCT1 functional interplayer, the $\mathrm{Na}^{+} / \mathrm{K}^{+}$ ATPase $\alpha 2$ subunit. Conversely, the MCT1 mRNA level was significantly raised in the cerebellum of Prnp $^{-/-}$vs. WT control group, without a substantial change in the $\mathrm{Na}^{+} / \mathrm{K}^{+}$ATPase $\alpha 2$ subunit expression. To validate the observed mRNA findings, we confirmed the observed change in MCT1 mRNA expression level in the cortex at the protein level. MCT4, highly expressed in tissues that rely on glycolysis as an energy source, exhibited a significant reduction in the hippocampus of Prnp $^{-/-}$vs. WT mice. The present study demonstrates that a lack of $\mathrm{PrP}^{\mathrm{C}}$ leads to altered MCT1 and MCT4 mRNA/protein expression in different brain regions of $\operatorname{Prnp}^{-/-}$vs. WT mice. Our findings provide evidence that $\mathrm{PrP}^{\mathrm{c}}$ might affect the monocarboxylate intercellular transport, which needs to be confirmed in further studies.
\end{abstract}

Keywords: cellular prion protein; prionprotein knockout; MCT1; MCT4; $\mathrm{Na}^{+} / \mathrm{K}^{+}$ATPase; cortex; qRT-PCR; Western blot

\section{Introduction}

$\mathrm{PrP}^{\mathrm{C}}$ is associated with heterologous biological processes. In the last few years, various reports have indicated the involvement of $\mathrm{PrP}^{\mathrm{C}}$ in the maintenance of glucose homeostasis [1-5]. Besides this, an effect of $\mathrm{PrP}^{\mathrm{C}}$ on glycolysis was suggested in several earlier studies [6-8]. A recent metabolomic analysis demonstrated reduced glycolysis and glucose utilization in the hippocampus and the cortex of prion-diseased mice [2]. Moreover, major alternations in mitochondrial metabolism were identified in the brain of sporadic Creutzfeldt-Jakob disease (sCJD) patients [9], which may be a consequence of $\operatorname{PrP}^{\mathrm{C}}$ loss of function. 
Deficits in glucose availability and disruption of mitochondrial functions were also seen in Alzheimer's disease (AD) patients [10]. Furthermore, an impairment of glycolysis was demonstrated to sensitize human astrocytes to amyloid beta toxicity and to induce amyloid aggregation [11]. Another recent study reported a decreased expression of monocarboxylate transporters (MCT1, MCT2, MCT4) and lactate dehydrogenase A and B (LDH$\mathrm{A}$ and LDH-B) in the brains of double transgenic amyloid precursor protein/presenilin 1 (APP/PS1) mouse model of AD [12]. MCTs are membrane-bound proteins with body-wide distribution, which enable the intercellular shuttling of energy metabolites such as lactate and pyruvate, whereas LDH isoenzymes enable the reversible conversion of pyruvate to lactate and thus play a critical role in glycolytic metabolism. Earlier, we showed that $\mathrm{PrP}^{\mathrm{C}}$ overexpression enhances MCT1 protein level in HEK 293 cells [13]. Interestingly, we also found that LDH-A and LDH-B protein expression levels were markedly increased in the brain of wild-type (WT) vs. Prnp knockout mice when exposed to ischemic (stress) conditions, but exhibited invariable expression under non-ischemic conditions [13]. The latter finding is significant in the light of a well-known fact that $\operatorname{PrP}^{\mathrm{c}}$ mice exhibit a higher tolerance toward different stress conditions as compared with $\mathrm{Prnp}^{-1-}$ mice $[14,15]$.

Lately, MCT1 mRNA levels have been shown to be markedly reduced in the frontal cortex of CJD MM1 and VV2 patients [16]. The cerebral cortex together with the cerebellum is one of the most frequently affected brain regions in CJD patients [17-19].

Therefore, we aimed to investigate if the presence/absence of $\operatorname{PrP}^{\mathrm{C}}$ in the cortex and the cerebellum of WT and $\mathrm{Prnp}^{-/-}$mice may directly influence MCT mRNA/protein expression levels along with additional genes involved in lactate/pyruvate energy metabolism, such as basigin, $L D H-A$ and $L D H-B$. In particular, the former protein is of interest because it is recognized as necessary for correct MCT1 localization and functioning [20]. Moreover, we investigated the hippocampus, in which important glucose metabolism changes were reported in prion-diseased mice [2].

\section{Results}

As to 3-month-old mice, 9-monthold $\mathrm{Prnp}^{-/-}$(Zurich I) mice showed various impairments during aging (appearing after 9 months) in comparison to WT mice (Supplementary Table S1) [21]. Young animals (e.g., after 3 months) exhibited no significant behavioral differences. Therefore, we expected the potential changes between both groups at a later time point. Animals older than 12-14 months generally showed age-related deficits (also in WT mice). That is why we considered 9 months of age as an optimal time point for our study.

In order to investigate if MCT1, MCT2 and MCT4 expression levels are modified in $\mathrm{Prnp}^{-1-}$ vs. WT mice, we employed qRT-PCR. The qRT-PCR results showed a marked four-fold downregulation of MCT1 mRNA expression in the cerebral cortex of $\mathrm{Prnp}^{-1-}$ as compared to WT mice $(p=0.0043)$ (Figure 1A). This finding was reproduced at the protein level with an approximately two- to three-fold decrease in MCT1 expression in the cerebral cortex of Prnp $^{-/-}$mice vs. WT mice after 9 months (Figure 2, $p<0.001$ ), but not after 3 months of age (Supplemental Figure S1A,B). Likewise, a small but significant decline in $\mathrm{Na}^{+} / \mathrm{K}^{+}$ATP-ase $\alpha 2$ subunit mRNA expression was observed in the same brain region of the Prnp $^{-/-}$mice $(p=0.0444)$ (Figure 1B). No changes were observed in the mRNA expressions of MCT2 and MCT4 (Figure 1C,D).

On the contrary, MCT1 was upregulated in the cerebellum of $\mathrm{Prnp}^{-/-}$vs. WT group ( $p=0.0068)$ (Figure 3A) without a significant change in $\mathrm{Na}^{+} \mathrm{K}^{+}$ATP-ase $\alpha 2$ subunit expression (Figure 3B). No significant differences in $M C T 2$ expression were detected between both experimental groups. However, a recognizable trend in MCT2 expression is apparent in the cerebellum, i.e., an increase in mRNA expression in the Prnp ${ }^{-1-}$ vs. WT group, which parallels the expressional increase in MCT1 in the cerebellum (Figure 3C). No change in MCT4 expression could be detected in the cerebellum (Figure 3D). 
A

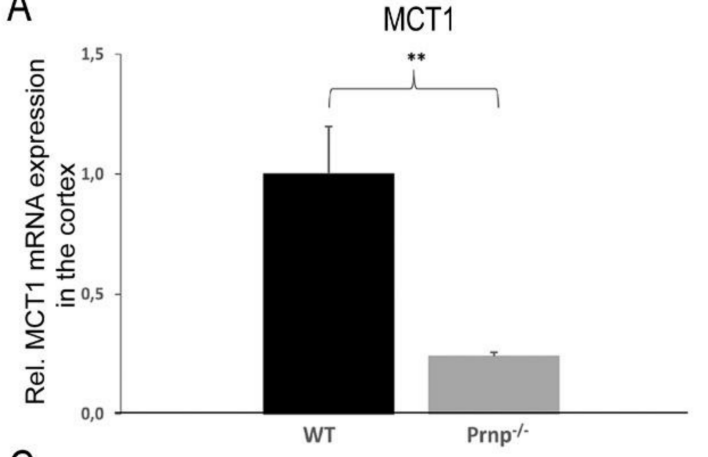

C

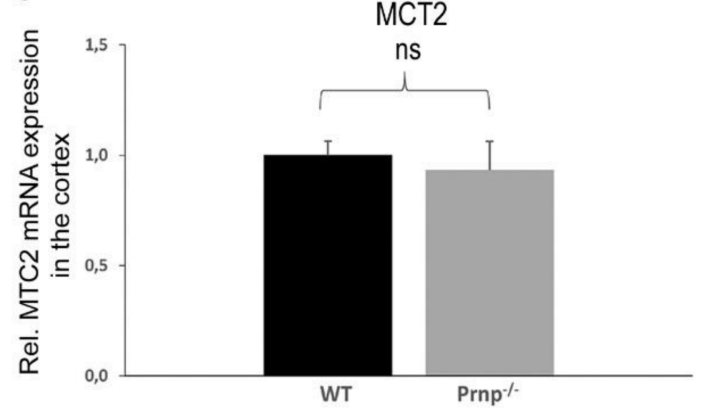

B

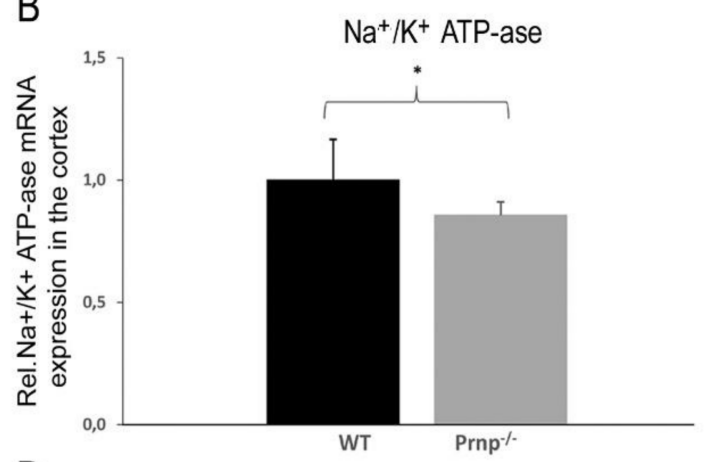

D

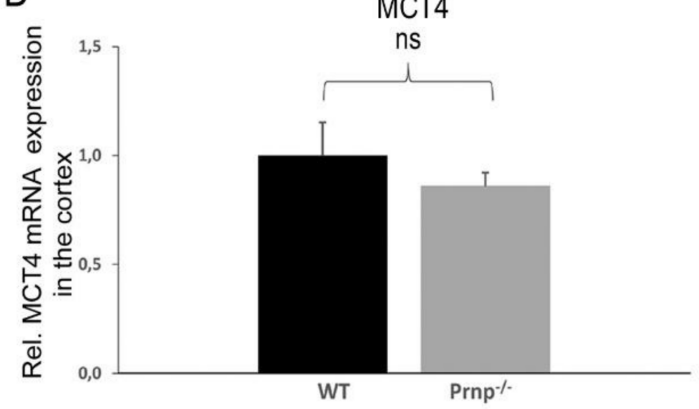

Figure 1. (A-D). Differential mRNA expression levels of monocarboxylate transporters $M C T 1, M C T 2, M C T 4$ and $N a^{+} / K^{+}$ ATP-ase $\alpha 2$ subunit in the cortex of WT and Prnp ${ }^{-/-}$mice. qRT-PCR analysis revealed a significant decrease in $M C T 1$ and $\mathrm{Na}^{+} / \mathrm{K}^{+}$ATP-ase $\alpha 2$ subunit expression in the cortex tissue of $\mathrm{Prnp}^{-/-}$as compared to a control group. Sample size of WT group: $n=5$; Prnp $^{-/}$group: $n=6$. Displayed are means \pm SEM. A $p$-value $<0.01$ is considered as very significant $\left({ }^{* *}\right)$, $<0.05$ as significant $\left(^{*}\right)$ and $\geq 0.05$ as not significant $(\mathrm{ns})$.

A

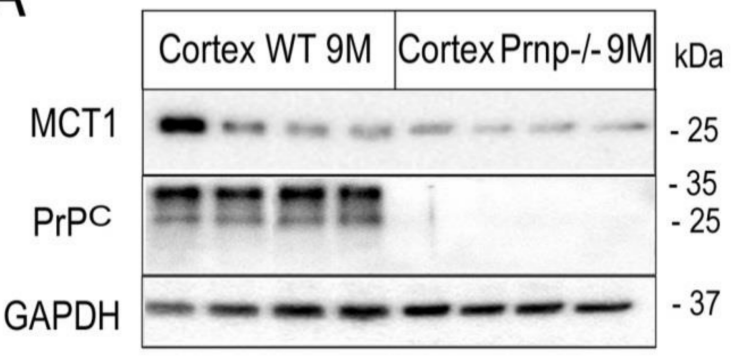

B

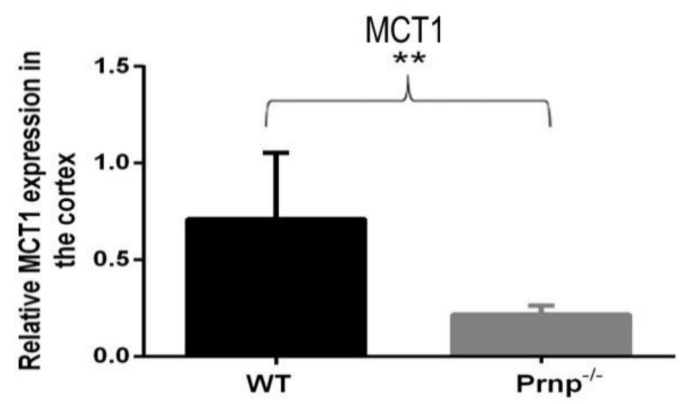

Figure 2. Western blot and densitometric analysis of MCT1 and $\mathrm{PrP}^{\mathrm{c}}$ expression in the cortex of 9-month-old WT and Prnp $^{-1-}$ mice. (A) Homogenates prepared from cortex were examined for MCT1 and PrPc expression by Western blotting. All brain homogenates of WT mice exhibited PrPc expression (diglycosylated at $35 \mathrm{kDa}$, monoglycosylated at $33 \mathrm{kDa}$ and unglycosylated at $26 \mathrm{kDa}$ ), whereas Prnp $^{-/-}$mice blots confirmed the absence of $\mathrm{PrP}^{\mathrm{c}}$. An equal protein load (20 $\mu \mathrm{g}$ per lane) is shown by GAPDH expression. (B) Densitometric quantification of band intensities via Image Lab 6.0.1 revealed a higher protein expression of MCT1 in WT as compared to Prnp ${ }^{-1-}$ mice. The analyses were performed on $n=4$ animals per group in three different Western blots. Displayed are means \pm SEM. A $p$-value $<0.01$ is considered as very significant $(* *)$.

In the hippocampus, no significant changes in expression could be found for MCT1 and MCT2 (Figure 4A,B). However, MCT4 exhibited an altered mRNA expression between the two experimental groups, in which there was a slight, but significant, MCT4 decrease found in Prnp ${ }^{-/-}$mice, as compared to their counterparts $(p=0.0366)$ (Figure 4C). No changes were noticed in the mRNA expression of basigin, $L D H-A$ or $L D H-B$ in any of the three brain regions tested (data not shown). 

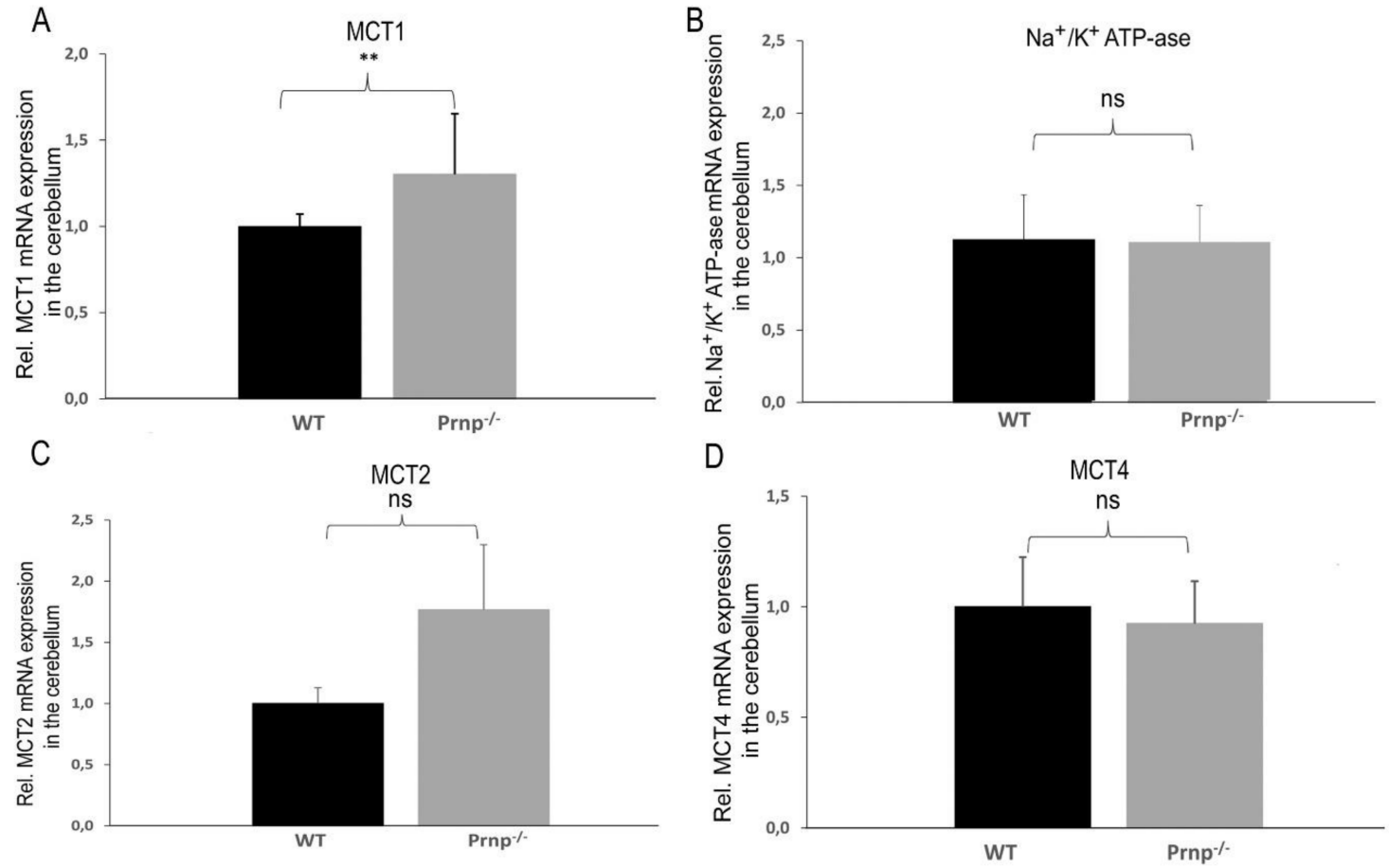

Figure 3. (A-D). Differential mRNA expression of $M C T 1, M C T 2, M C T 4$ and $N a^{+} / K^{+}$ATP-ase $\alpha 2$ subunit in the cerebellum of WT and Prnp $^{-/-}$mice. The mRNA expression level of MCT1 was significantly increased in the cerebellum of Prnp ${ }^{-/-}$vs. a control group, while $\mathrm{MCT} 2, \mathrm{MCT} 4$ and $\mathrm{Na}^{+} / \mathrm{K}^{+}$ATP-ase $\alpha 2$ subunit expression remained unchanged. Sample size of WT group: $n=5 ;$ Prnp $^{-/-}$group: $n=6$. Displayed are means \pm SEM. A $p$-value $<0.01$ is considered as very significant $(* *)$ and $\geq 0.05$ as not significant (ns).
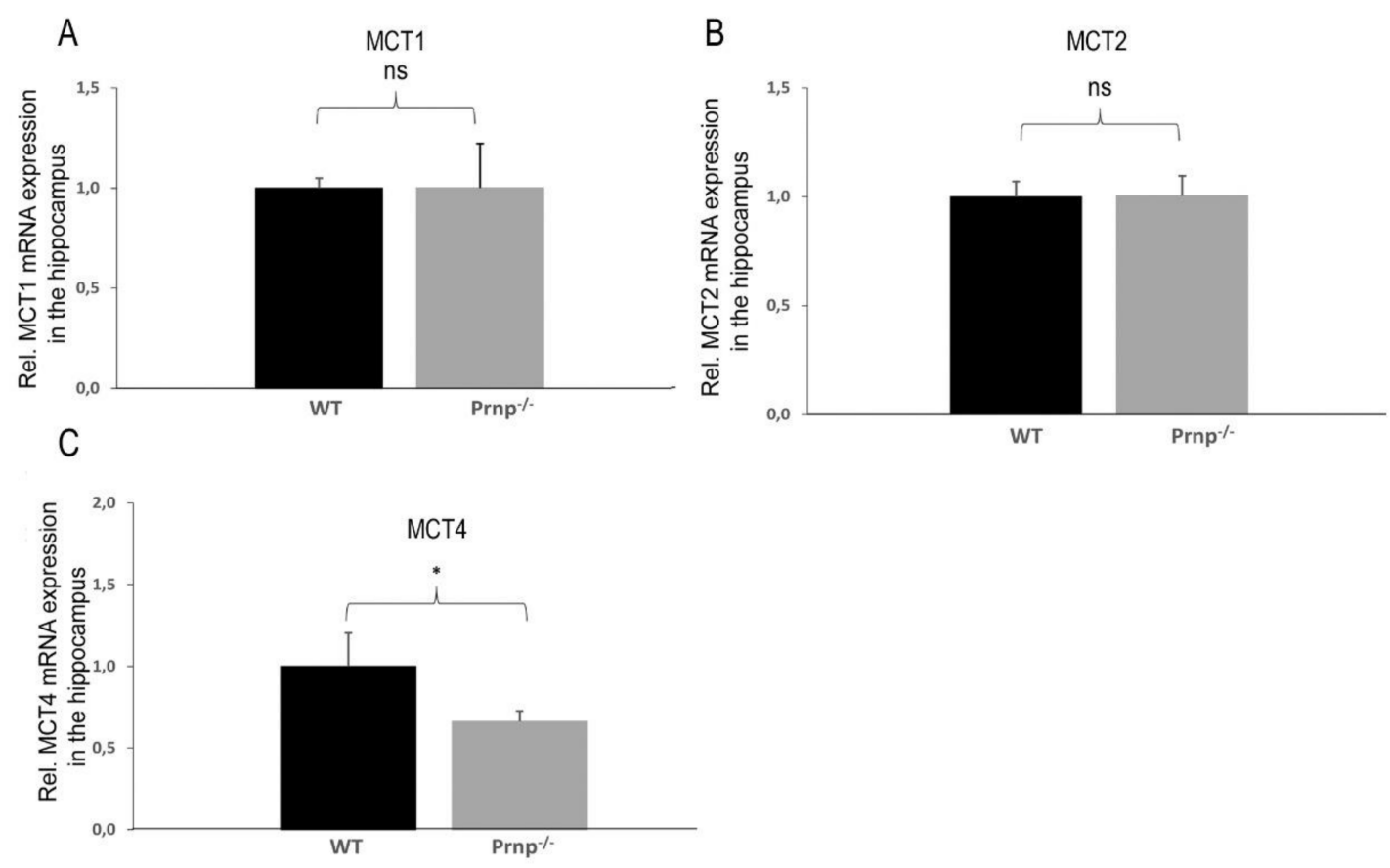

Figure 4. (A-C). Differential mRNA expression of MCT1, MCT2 and MCT4 in the hippocampus of WT and Prnp ${ }^{-/-}$mice. Quantification of the mRNA expression revealed a lower MCT4 expression in the hippocampus of the Prnp ${ }^{-/-}$experimental $^{-}$ group than in control group, while at the same time levels of MCT1 and MCT2 were unaltered. Sample size of WT group: $n=5 ;$ Prn $^{-/-}$group: $n=6$. Displayed are means \pm SEM. A $p$-value $<0.05$ is considered as significant $\left({ }^{*}\right)$ and $\geq 0.05$ as not significant (ns). 


\section{Discussion}

Up to now, the understanding of $\mathrm{PrP}^{\mathrm{c}}$ 's role in neuroenergetic processes has been limited. Therefore, we examined if a lack of $\mathrm{PrP}^{\mathrm{c}}$ may modulate the expression of genes known to be critically involved in supporting unobstructed glycolytic processes that are of utmost importance, especially under stress conditions when energy demand is high.

As a model we chose 9-month-old WT and $\mathrm{Prnp}^{-/-}$mice because of aging-related behavioral changes in $\mathrm{Prnp}^{-/}$mice starting at this age [21], and we propose an association between behavioral deficits and the energy metabolism.

In the present study, we found that the mRNA expression levels of MCT1 and MCT4 as well as $\mathrm{Na}^{+} / \mathrm{K}^{+}$-ATPase $\alpha 2$ subunit are considerably changed in either the cortex, the cerebellum or the hippocampus of $\mathrm{Prnp}^{-/-}$vs. WT mice. Additionally, we showed that MCT1 protein levels in the cortex are upregulated in 9-month-old WT mice as compared to Prnp $^{-/-}$mice (behavioral changes between both groups obvious in respect to learning, anxiety, curiosity), but not in 3-month-old mice (no behavioral changes between both groups obvious). This finding hints at the association of the presence/absence of $\mathrm{PrP}^{\mathrm{c}}$, changes in MCTs mRNA/protein expression and potential impact on neuroenergetics.

Reduced PRNP mRNA expression levels were previously observed in the frontal cortex of sCJD patients [22], where the cellular function of $\operatorname{PrP}$ was lost due its conversion to $\operatorname{PrP}$ scrapie, and the abnormal imaging patterns detectable in the cerebral cortex of CJD-affected patients are well characterized [23]. MCT1 mRNA expression and immunoreactivity were identified as markedly diminished in the same brain area of SCJD as compared to control patients [16]. Therefore, investigating the differential cortical mRNA expression of genes engaged in neuroenergetics seemed to be a relevant issue.

A four-fold downregulation of MCT1 mRNA and protein expression, observed in the present study in the cortex of $\mathrm{Prnp}^{-/-}$mice vs. WT mice, suggests the inadequate intercellular transport of lactate and/or pyruvate, which may be a consequence of a lack of $\mathrm{PrP}^{\mathrm{c}}$. This finding is in concordance with the above-mentioned reduced MCT1 cortical mRNA and protein expression shown in SCJD patients [16]. Another report demonstrated that the downregulation of MCT1 in glioma cells results in decreased lactate production [24]. The knockdown of MCT1 results in aberrant axon morphology and neuronal death, a phenotype that could be rescued by supplying lactate [25]. Important disturbances in lactate metabolism were previously detected in the brain of Prnp knockout mice [26].

Kleene at al. 2007 [27] stated that $\mathrm{PrP}^{\mathrm{C}}$ regulates lactate transport via MCT1 in cultured astrocytes conjointly with $\mathrm{Na}^{+} / \mathrm{K}^{+} \alpha 2 / \beta 2$ ATPase and basigin, and that the activity of the former is reduced in PrP-deficient astrocytes. We observed significantly lowered $\mathrm{Na}^{+} / \mathrm{K}^{+}$ ATPase $\alpha 2$ subunit mRNA expression levels in $\mathrm{Prnp}^{-/-}$vs. WT mice, and no difference in the expression of basigin that directly interacts with the $\mathrm{Na}^{+} / \mathrm{K}^{+}$ATPase $\alpha 2$ subunit. Glutamate uptake is known to stimulate aerobic glycolysis in astrocytes by activating the $\alpha 2$ subunit of the $\mathrm{Na}^{+} / \mathrm{K}^{+}$ATPase [28]. A two-fold reduction in neuronal and astroglial $\mathrm{Na}^{+}$-dependent glutamate uptake was detected in the absence of $\operatorname{PrP}^{\mathrm{c}}[29]$.

Interestingly, MCT1 was slightly but significantly elevated in the cerebellum of Prnp ${ }^{-/-}$mice and a marked upward trend was seen in the MCT2 expression.

MCT4, another monocarboxylate proton-coupled transporter, showed slight but significant downregulation in the hippocampus of $\mathrm{Prnp}^{-/-}$vs. WT mice, suggesting an impaired lactate export from astrocytes to neurons. Disrupting the expression of MCT1 or MCT4 (glial transporters), and/or MCT2 (neuronal transporter), in the rat hippocampus prevented learning and long-term memory formation. The latter deficiency could be rescued by exogenously provided lactate [30], underlining the importance of lactate shuttling from astrocytes to neurons. Amongst the most prominent phenotypes of $\mathrm{Prnp}^{-/-}$mice are cognitive deficits and memory impairment [31]. Astrocytes are known to export lactate either through MCT1 or MCT4 to power oxidative neurons expressing MCT2 [32]. A bidirectional impact of the activity between cerebellum and hippocampus has been demonstrated [33]. Although the role of the cerebellum in cognitive functions is still controversial, there is growing evidence of its contributions to cognitive functions, such as attention, language, 
working memory, and visuospatial navigation [34,35]. Therefore, it is conceivable that all three brain structures cooperate in a compensatory way at the energetic level, and therefore show differential up-/downregulation of MCTs as compared to each other.

No differential regulation of LDH-A or LDH-B could be evidenced between the two experimental groups in the present study, which is in concordance with earlier results [13] that showed that the expression levels of both LDH isoenzymes increase in WT vs. Prnp ${ }^{-1-}$ mice solely following hypoxic injury.

Investigating the expression levels of MCTs and other genes important for the optimal execution of neuroenergetic processes in WT vs. Prnp ${ }^{-1}$ mice after exposure to hypoxia (stress condition) appears to be a proper approach to verifying if the increased infarction volumes observed in $\mathrm{Prnp}^{-1-}$ mice may be a consequence of the disturbed expression of MCTs and glycolysis. As such, $\mathrm{PrP}^{\mathrm{C}}$ emerges as a novel protein that may prove importantance for the regulation of MCT1 and MCT4 expression, and its lack or loss of function may thereby accelerate the process of neurodegeneration.

\section{Material and Methods}

\subsection{Animals}

Zürich I Prnp ${ }^{-/-}$mice of the C57BL/6J genetic background were generated as previously described by Bueler et al. [36]. As controls, we used WT mice from the same genetic background. The body weight of all animals varied between 25 and $35 \mathrm{~g}$ and they were either 3 or 9 months-old. Prnp ${ }^{-/-}$mice showed age-dependent behavioral abnormalities as given in the Supplementary Table S1 and and earlier reports [21,37]. Five (WT group) and six $\left(\mathrm{Prnp}^{-1-}\right.$ group) animals per experimental group were tested for differential mRNA expression levels.

\subsection{Brain Homogenates for RNA Preparation}

After euthanization by cervical dislocation, mouse brains were dissected on ice and collected cortices were lysed and homogenized in $350 \mu \mathrm{L}$ lysis buffer (RLT Buffer, Qiagen) using the VWR Pellet mixer (VWR, Dietikon, Switzerland) according to the manufacturer's instructions. Total RNA was isolated on spin columns with silica-based membranes (RNeasy Mini Kit, Qiagen, Basel, Switzerland), following the manufacturer's instructions. RNA was eluted with $30 \mu \mathrm{L}$ of $\mathrm{H}_{2} \mathrm{O}$. Two hundred ng of purified RNA was reverse transcribed in a volume of $50 \mu \mathrm{L}$ using the RT High Capacity RNA-to-cDNA Kit (Applied Biosystems, Rotkreuz, Switzerland). Quantitative real-time PCR analysis was performed on cDNA obtained with the Applied Biosystems ViiA ${ }^{\mathrm{TM}} 7$ (Applied Biosystems, Rotkreuz, Switzerland) Real-Time PCR System using Power SYBR Green Taq polymerase master mix (Applied Biosystems, Rotkreuz, Switzerland). Primer sequences used for mRNA quantification were directed against $L D H-A, L D H-B$, basigin, $\mathrm{Na}^{+} / \mathrm{K}^{+} A T P a s e ~ \alpha 2$ subunit, MCT1, MCT2 and MCT4 mRNAs, as well as $\beta$-Actin mRNA used as an endogenous control (See Table 1 for sequences). For data analysis, the raw threshold cycle (CT) value was first normalized to the endogenous control for each sample to obtain the ${ }^{\Delta} \mathrm{CT}$ value. The normalized ${ }^{\Delta} \mathrm{CT}$ value was then calibrated to the control cell samples to obtain the $2^{-\Delta \Delta C T}$.

\subsection{Primer Sequence}

The list of all forward and reverse sequences used for qRT-PCR experiments is provided in Table 1.

\subsection{Protein Analysis \\ Brain Homogenates}

After euthanization by cervical dislocation, mouse brains were dissected on ice into three different brain regions: hippocampus $(\mathrm{H})$, cortex $(\mathrm{C})$, cerebellum $(\mathrm{CB})$. Samples were homogenized in homogenization buffer ( $50 \mathrm{mM}$ Tris $\mathrm{HCl}$ (pH 7.5), $150 \mathrm{mM} \mathrm{NaCl}, 2 \mathrm{mM}$ EDTA, $1 \%$ Triton X-100 and protease inhibitors), sonicated for $5 \mathrm{~min}$ in a water bath and incubated with rotation for $15 \mathrm{~min}$. Insoluble debris was removed by a centrifugation step 
for $20 \mathrm{~min}$ at $13,000 \times g$ at $4{ }^{\circ} \mathrm{C}$. The supernatant was transferred to a separate tube and stored at $-80^{\circ} \mathrm{C}$.

Table 1. List of primer sequences used in qRT-PCR experiments.

\begin{tabular}{ccc}
\hline Name & Forward Sequence & Reverse Sequence \\
\hline$L H-A$ & CAGTGGCTTTGCCAAAAACCGAGT & CCATCAGGTAACGGAACCGCG \\
LDH- $B$ & CCTGCTGACTTTGCAGTGGCTCC & TCGCCGCGGCAGCCTCATCAT \\
Basigin & CAAGGTACTGCAGGAGGACACTCT & TCAGGAAGGAAGATGCAGGAATATT \\
$\mathrm{Na}^{+} / \mathrm{K}^{+}-$ATPase $\alpha 2$ & GAGACGCGCAATATCTGTTTCTT & ACCTGTGGCAATCACAATGC \\
$M C T 1$ & TTGGACCCCAGAGGTTCTCC & AGGCGGCCTAAAAGTGGTG \\
$M C T 2$ & CAGCAACAGCGTGATAGAGCTT & TGGTTGCAGGTTGAATGCTAAT \\
$M C T 4$ & CGGCTGGCGGTAACAGAGTA & CGGCCTCGGACCTGAGTATT \\
$\beta$-Actin & GCTTCTTTGCAGCTCCTTCGT & ATATCGTCATCCATGGCGAAC \\
\hline
\end{tabular}

\subsection{Western Blotting}

For Western blot analysis we used the monoclonal anti-MCT1 (Abcam, Cambridge, UK) diluted 1:500, anti-PrP antibody SAF70 (SPI-Bio, Montigny Le Bretonneux, Paris, France) diluted 1:500, and monoclonal GAPDH antibody diluted 1:5000 (Abcam, Cambridge, UK). We followed a standard protocol published before [21]. After Western blotting detection, bands were analyzed via Chemi-Doc (Bio-Rad, Munich, Germany). A densitometric analysis of band intensities was performed with Image Lab software version 6.0.1.

\subsection{Ethics Approval}

The study was approved by the Lower Saxony State Office for Consumer Protection and Food Safety (No. 16/2073).

\subsection{Statistical Analysis}

Results are presented as means \pm SEM (standard error of the mean). Statistical analysis was performed using GraphPad Prism 8 software. Normality was tested with the KolmogorovSmirnov test. Depending on the result of the normality test, an unpaired Student's $t$-test or an unpaired $t$-test with Welch's correction (when equal variance was not assumed) was used. Moreover, we performed an animal experimentation sample size calculation to estimate the number of animals required to attain statistical significance. Significant differences are indicated for $p$-values of $<0.05,<0.01$, or $<0.001$. All qRT-PCR and western blotting experiments were performed in triplicates.

Supplementary Materials: The following are available online at https://www.mdpi.com/1422-0 067/22/4/1566/s1, Table S1: Overview on mice behavioral deficits in Prnp $^{-/-}$mice during aging (adapted from Schmitz et al., 2014a). Figure S1A,B. Western blot and densitometric analysis of MCT1 and $\operatorname{PrP}^{\mathrm{C}}$ expression in the cortex of 3-month-old WT and Prnp ${ }^{-/-}$mice. MCT1 expression was not significantly changed in 3-month-old WT as compared to Prnp ${ }^{-/-}$mice.

Author Contributions: Conceptualization: S.R., M.S. and L.P.; Methodology: M.S., C.R.; Valida-tion: I.Z., L.P.; Formal Analysis: S.R., M.S., C.R.; Resources: I.Z., L.P.; Writing-Original Draft Preparation: S.R.; Writing-Review \& Editing: M.S., I.Z., L.P.; Funding Acquisition, L.P. All authors have read and agreed to the published version of the manuscript.

Funding: L.P. received financial support for this project from the Department of Physiology, University of Lausanne and from the program IdEx Bordeaux ANR-10-IDEX-03-02.

Institutional Review Board Statement: The study was conducted according to the guidelines of the Declaration of Helsinki, and approved by the Institutional Review Board (or Ethics Committee) of Lower Saxony State Office for Consumer Protection and Food Safety (protocol code No. 16/2073; date 28 July 2017).

Informed Consent Statement: Not applicable.

Conflicts of Interest: The authors declare no conflict of interest. 


\section{References}

1. Ashok, A.; Singh, N. Prion protein modulates glucose homeostasis by altering intracellular iron. Sci. Rep. 2018, 8, 6556. [CrossRef] [PubMed]

2. Bourgognon, J.M.; Spiers, J.G.; Scheiblich, H.; Antonov, A.; Bradley, S.J.; Tobin, A.B.; Steinert, J.R. Alterations in neuronal metabolism contribute to the pathogenesis of prion disease. Cell Death Differ. 2018, 25, 1408-1425. [CrossRef]

3. Brito, G.; Roffe, M.; Lupinacci, F.; Santos, T.; Beraldo, F.; Martins, V.R.; Hajj, G.N. The role of cellular prion protein in the regulation of insulin signaling. Mol. Biol. Cell 2013, 24, 3775. [CrossRef]

4. Strom, A.; Wang, G.S.; Reimer, R.; Finegood, D.T.; Scott, F.W. Pronounced cytosolic aggregation of cellular prion protein in pancreatic beta-cells in response to hyperglycemia. Lab. Investig. 2007, 87, 139-149. [CrossRef] [PubMed]

5. Strom, A.; Wang, G.S.; Scott, F.W. Impaired glucose tolerance in mice lacking cellular prion protein. Pancreas 2011, 40, $229-232$. [CrossRef]

6. Gawinecka, J.; Dieks, J.; Asif, A.R.; Carimalo, J.; Heinemann, U.; Streich, J.H.; Dihazi, H.; Schulz-Schaeffer, W.; Zerr, I. Codon 129 polymorphism specific cerebrospinal fluid proteome pattern in sporadic Creutzfeldt-Jakob disease and the implication of glycolytic enzymes in prion-induced pathology. J. Proteome Res. 2010, 9, 5646-5657. [CrossRef]

7. Li, Q.Q.; Sun, Y.P.; Ruan, C.P.; Xu, X.Y.; Ge, J.H.; He, J.; Xu, Z.D.; Wang, Q.; Gao, W.C. Cellular prion protein promotes glucose uptake through the Fyn-HIF-2 $\alpha$-Glut1 pathway to support colorectal cancer cell survival. Cancer Sci. 2011, 102, $400-406$. [CrossRef]

8. Ramljak, S.; Herlyn, H.; Zerr, I. Cellular Prion Protein $\left(\mathrm{PrP}^{\mathrm{c}}\right)$ and hypoxia: True to each other in good times and in bad, in sickness, and in health. Front. Cell. Neurosci. 2016, 10, 292. [CrossRef]

9. Ansoleaga, B.; Garcia-Esparcia, P.; Llorens, F.; Hernández-Ortega, K.; Carmona Tech, M.; Antonio Del Rio, J.; Zerr, I.; Ferrer, I. Altered mitochondria, protein synthesis machinery, and purine metabolism are molecular contributors to the pathogenesis of Creutzfeldt-Jakob Disease. J. Neuropathol. Exp. Neurol. 2016, 75, 755-769. [CrossRef] [PubMed]

10. Yin, F.; Sancheti, H.; Patil, I.; Cadenas, E. Energy metabolism and inflammation in brain aging and Alzheimer's disease. Free Radic. Biol. Med. 2016, 100, 108-122. [CrossRef]

11. Fu, W.; Shi, D.; Westaway, D.; Jhamandas, J.H. Bioenergetic mechanisms in astrocytes may contribute to amyloid plaque deposition and toxicity. J. Biol. Chem. 2015, 290, 12504-12513. [CrossRef] [PubMed]

12. Zhang, M.; Cheng, X.; Dang, R.; Zhang, W.; Zhang, J.; Yao, Z. Lactate deficit in an Alzheimer disease mouse model: The relationship to neuronal damage. J. Neuropathol. Exp. Neurol. 2018, 77, 1163-1176. [CrossRef] [PubMed]

13. Ramljak, S.; Schmitz, M.; Zafar, S.; Wrede, A.; Schenkel, S.; Asif, A.R.; Carimalo, J.; Doeppner, T.R.; Schulz-Schaeffer, W.J.; Weise, J.; et al. Cellular prion protein directly interacts with and enhances lactate dehydrogenase expression under hypoxic conditions. Exp. Neurol. 2015, 271, 155-167. [CrossRef] [PubMed]

14. McLennan, N.F.; Brennan, P.M.; McNeill, A.; Davies, I.; Fotheringham, A.; Rennison, K.A.; Ritchie, D.; Brannan, F.; Head, M.W.; Ironside, J.W.; et al. Prion protein accumulation and neuroprotection in hypoxic brain damage. Am. J. Pathol. 2004, 165, 227-235. [CrossRef]

15. Mitteregger, G.; Vosko, M.; Krebs, B.; Xiang, W.; Kohlmannsperger, V.; Nölting, S.; Hamann, G.F.; Kretzschmar, H.A. The role of the octarepeat region in neuroprotective function of the cellular prion protein. Brain Pathol. 2007, 17, 174-183. [CrossRef]

16. Andres-Benito, P.; Dominguez-Gonzalez, M.; Ferrer, I. Altered gene transcription linked to astrocytes and oligodendrocytes in frontal cortex in Creutzfeldt-Jakob disease. Prion 2018, 12, 216-225. [CrossRef]

17. Ferrer, I.; Puig, B.; Blanco, R.; Martí, E. Prion protein deposition and abnormal synaptic protein expression in the cerebellum in Creutzfeldt-Jakob disease. Neuroscience 2000, 97, 715-726. [CrossRef]

18. Tschampa, H.J.; Kallenberg, K.; Kretzschmar, H.A.; Meissner, B.; Knauth, M.; Urbach, H.; Zerr, I. Pattern of cortical changes in sporadic Creutzfeldt-Jakob disease. AJNR Am. J. Neuroradiol. 2007, 28, 1114-1118. [CrossRef]

19. Meissner, B.; Kallenberg, K.; Sanchez-Juan, P.; Ramljak, S.; Krasnianski, A.; Heinemann, U.; Eigenbrod, S.; Gelpi, E.; Barsic, B.; Kretzschmar, H.A.; et al. MRI and clinical syndrome in dura mater-related Creutzfeldt-Jakob disease. J. Neurol. 2009, 256, 355-363. [CrossRef]

20. Maekawa, F.; Minehira, K.; Kadomatsu, K.; Pellerin, L. Basal and stimulated lactate fluxes in primary cultures of astrocytes are differentially controlled by distinct proteins. J. Neurochem. 2008, 107, 789-798. [CrossRef]

21. Schmitz, M.; Greis, C.; Ottis, P.; Silva, C.J.; Schulz-Schaeffer, W.J.; Wrede, A.; Koppe, K.; Onisko, B.; Requena, J.R.; Govindarajan, N.; et al. Loss of prion protein leads to age-dependent behavioral abnormalities and changes in cytoskeletal protein expression. Mol. Neurobiol. 2014, 50, 923-936. [CrossRef]

22. Llorens, F.; Ansoleaga, B.; Garcia-Esparcia, P.; Zafar, S.; Grau-Rivera, O.; López-González, I.; Blanco, R.; Carmona, M.; Yagüe, J.; Nos, C.; et al. PrP mRNA and protein expression in brain and $\operatorname{PrP}^{\mathrm{C}}$ in CSF in Creutzfeldt-Jakob disease MM1 and VV2. Prion 2013, 7, 383-393. [CrossRef]

23. Fragoso, D.C.; Goncalves Filho, A.L.; Pacheco, F.T.; Barros, B.R.; Aguiar Littig, I.; Nunes, R.H.; Maia Júnior, A.C.; da Rocha, A.J. Imaging of Creutzfeldt-Jakob disease: Imaging patterns and their differential diagnosis. Radiographics 2017, 37, $234-257$. [CrossRef]

24. Miranda-Gonçalves, V.; Granja, S.; Martinho, O.; Honavar, M.; Pojo, M.; Costa, B.M.; Pires, M.M.; Pinheiro, C.; Cordeiro, M.; Bebiano, G.; et al. Hypoxia-mediated upregulation of MCT1 expression supports the glycolytic phenotype of glioblastomas. Oncotarget 2016, 7, 46335-46353. [CrossRef] 
25. Lee, Y.; Morrison, B.M.; Li, Y.; Lengacher, S.; Farah, M.H.; Hoffman, P.N.; Liu, Y.; Tsingalia, A.; Jin, L.; Zhang, P.W.; et al. Oligodendroglia metabolically support axons and contribute to neurodegeneration. Nature 2012, 487, 443-448. [CrossRef]

26. Cudalbu, C.; Craveiro, M.; Mlynárik, V.; Bremer, J.; Aguzzi, A.; Gruetter, R. In Vivo longitudinal (1)H MRS study of transgenic mouse models of prion disease in the hippocampus and cerebellum at 14.1 T. Neurochem. Res. 2015, 40, 2639-2646. [CrossRef]

27. Kleene, R.; Loers, G.; Langer, J.; Frobert, Y.; Buck, F.; Schachner, M. Prion protein regulates glutamate-dependent lactate transport of astrocytes. J. Neurosci. 2007, 27, 12331-12340. [CrossRef]

28. Pellerin, L.; Bouzier-Sore, A.K.; Aubert, A.; Serres, S.; Merle, M.; Costalat, R.; Magistretti, P.J. Activity-dependent regulation of energy metabolism by astrocytes: An update. Glia 2007, 55, 1251-1262. [CrossRef]

29. Guitart, K.; Loers, G.; Schachner, M.; Kleene, R. Prion protein regulates glutathione metabolism and neural glutamate and cysteine uptake via excitatory amino acid transporter 3. J. Neurochem. 2015, 133, 558-571. [CrossRef]

30. Suzuki, A.; Stern, S.A.; Bozdagi, O.; Huntley, G.W.; Walker, R.H.; Magistretti, P.J.; Alberini, C.M. Astrocyte-neuron lactate transport is required for long-term memory formation. Cell 2011, 144, 810-823. [CrossRef]

31. Steele, A.D.; Lindquist, S.; Aguzzi, A. The prion protein knockout mouse: A phenotype under challenge. Prion 2007, 1, 83-93. [CrossRef]

32. Pérez-Escuredo, J.; Van Hée, V.F.; Sboarina, M.; Falces, J.; Payen, V.L.; Pellerin, L.; Sonveaux, P. Monocarboxylate transporters in the brain and in cancer. Biochim. Biophys. Acta 2016, 1863, 2481-2497. [CrossRef]

33. Yu, W.; Krook-Magnuson, E. Cognitive Collaborations: Bidirectional functional connectivity between the cerebellum and the hippocampus. Front. Syst. Neurosci. 2015, 9, 177. [CrossRef]

34. Bohne, P.; Schwarz, M.K.; Herlitze, S.; Mark, M.D. A new projection from the deep cerebellar nuclei to the hippocampus via the ventrolateral and laterodorsal thalamus in mice. Front. Neural Circuits 2019, 13, 51. [CrossRef]

35. Watson, T.C.; Becker, N.; Apps, R.; Jones, M.W. Back to front: Cerebellar connections and interactions with the prefrontal cortex. Front. Syst. Neurosci. 2014, 8, 4. [CrossRef]

36. Bueler, H.; Fischer, M.; Lang, Y.; Bluethmann, H.; Lipp, H.P.; DeArmond, S.J.; Prusiner, S.B.; Aguet, M.; Weissmann, C. Normal development and behavior of mice lacking the neuronal cell-surface PrP protein. Nature 1992, 356, 577-582. [CrossRef]

37. Schmitz, M.; Zafar, S.; Silva, C.J.; Zerr, I. Behavioral abnormalities in prion protein knockout mice and the potential relevance of $\mathrm{PrP}^{\mathrm{C}}$ for the cytoskeleton. Prion 2014, 8, 381-386. [CrossRef] 